\title{
KOMODITAS PADI: TELAAH KEHILANGAN HASIL SAAT PANEN DI KABUPATEN JOMBANG
}

\author{
(PADDY COMMODITY: ANALYSIS OF HARVEST LOSSES \\ IN JOMBANG DISTRICT)
}

\section{Syarif Imam Hidayat*, Setyo Parsudi, Gerin Lingga Ayu Mustika Putri}

\author{
Program Studi Agribisnis, Fakultas Pertanian, \\ Universitas Pembangunan Nasional "Veteran" Jawa Timur \\ *Email: syarifimamhidayat@yahoo.com \\ (Diterima 4-1-2021; Disetujui 18-1-2021)
}

\begin{abstract}
ABSTRAK
Penelitian dilaksanakan di Kecamatan Mojowarno, Kecamatan Ngoro dan Kecamatan Peterongan Kabupaten Jombang, mulai bulan Maret - April 2020, pada areal ushatani Padi. Tujuan penelitian adalah untuk menghitung besar kehilangan hasil panen dan nilai kerugian, menganalisis faktorfaktor yang mempengaruhi kehilangan hasil panen, upaya dan tindakan stratetgis petani dan pemerintah untuk mengurangi kehilangan hasil panen. Kehilangan hasil dalam penelitian ini meliputi: kegiatan pemanenan, penumpukan, perontokan, dan pengeringan Metode penelitian yang digunakan adalah metode deskriptif kuantitatif dengan teknik penentuan responden menggunakan kuota sampling sebanyak 75 orang yang merupakan masyarakat petani di tiga kecamatan Kabupaten Jombang. Teknik analisis yang digunakan yaitu metode penghitungan matematis besar kehilangan dan nilai kerugian (Riska, 2016), regresi linier berganda, uji asumsi klasik dan deskriptif. Hasil dari penelitian menunjukan bahwa besar kehilangan hasil panen per hektar sebesar $12,7 \%$ dan nilai kerugian Rp.5.945.386,2,- Melalui metode regresi linier berganda diperoleh bahwa terdapat pengaruh signifikan luas lahan, umur panen, perilaku petani, varietas, alat dan cara panen, alat perontok serta musim terhadap kehilangan hasil panen sebesar $70,9 \%$ sisanya $20,1 \%$ merupakan faktor lain yang tidak diteliti. Upaya strategis yang dapat dilakukan untuk petani menggunakan tenaga pemanen borongan, panen tepat waktu, mengurangi perontokan gabah di rumah, mengurangi penggunaan Varietas padi mudah rontok dan mengurangi pengumpulan sebelum perontokan. Bagi Pemerintah dapat dilakukan dengan cara meningkatkan kemampuan dan keterampilan petani (capacity building), memanfaatkan teknologi tepat guna.sesuai lokasi, membentuk dan memberdayakan kelompok tani.
\end{abstract}

Kata Kunci : Kehilangan Hasil, Padi

\begin{abstract}
The research was conducted in Mojowarno District, Ngoro District and Peterongan District, Jombang Regency, from March to April 2020, in the rice field area. The aim of this research is to calculate the amount of yield loss and the value of the loss, to analyze the factors that influence the loss of yields, the efforts and strategic actions of farmers and the government to reduce yield losses. The missing results in this study include: harvesting, heaping, threshing, and drying activities. The research method used is descriptive quantitative method with the respondent determination technique using quota sampling of 75 people who are farmers in three sub-districts of Jombang Regency. The analysis technique used is the method of calculating the amount of loss and loss value (Riska, 2016), multiple linear regression, classical and descriptive assumption tests. The results of the study showed that the yield loss per hectare was $12.7 \%$ and the loss value was Rp.5,945,386.2, - Through the multiple linear regression method, it was found that there was a significant influence on land area, harvest age, farmer behavior, varieties, tools and the method of harvesting, thresher tools and the season for the loss of crop yields of 70.9\% and the remaining $20.1 \%$ are other factors not examined. Strategic efforts that can be made for farmers are to use
\end{abstract}


wholesale harvesting power, harvest on time, reduce threshing of grain at home, reduce the use of easy-to-fall rice varieties and reduce collection before threshing. For the government, this can be done by increasing the capacity and skills of farmers (capacity building), utilizing appropriate technology according to location, forming and empowering farmer groups.

Keywords: Loss of Yield, Rice

\section{PENDAHULUAN}

Peningkatan jumlah penduduk di abad ke-21 tidak dapat dihindari, sehingga meningkatnya populasi penduduk dunia akan memerlukan peningkatkan sumber daya, baik sumber daya air, tanah, udara dan khususnya sumber daya pangan. Penduduk dunia diperkirakan akan mencapai 9,1 milyar pada tahun 2050 (Hodges, et al, 2012). Peningkatan jumlah penduduk tersebut memerlukan peningkatan produksi pangan hingga 70\% (FAO, 2009). Peningkatan kebutuhan pangan menjadi persoalan yang sangat strategis dan membutuhkan penanganan yang serius khususnya komoditas pangan strategis, seperti beras. Beras merupakan kebutuhan pangan utama bagi sebagian besar penduduk dunia, khususnya di Indonesia. Indonesia sebagai negara berkembang, juga merupakan salah satu pemasok beras terbesar di Asia Tenggara mengalami problem dengan ketersediaan beras. Tingkat produksi yang tinggi di Indonesia belum mampu memenuhi kebutuhan beras 252,2 juta penduduk Indonesia pada tahun 2014. Hal ini dibuktikan masih tingginya impor beras pada tahun tersebut yaitu sebesar 844,2 ribu ton (BPS, 2015). Belum terpenuhinya kebutuhan beras murni dari produksi dalam negeri disebabkan oleh berbagai faktor, antara lain karena kehilangan pascapanen dan distribusi (food loss). FAO (2011) menyebutkan bahwa $33,33 \%$ pangan yang di produksi dunia hilang atau tercecer. Selama ini peningkatan ketersediaan beras di Indonesia fokus pada peningkatan produksi dan upaya pemenuhan dengan melakukan impor.

Badan Penelitian dan Pengembangan Pertanian Kementerian Pertanian pada tahun 2014 merilis bahwa komoditas beras merupakan komoditas yang memiliki persentase kehilangan hasil paling tinggi diantara komoditas serelia dan kacang-kacangan. Data kehilangan mencapai 9,49\% pada tahap pemanenan, 4,81\% pada tahap pengumpulan, $2,17 \%$ pada tahap perontokan, dan 2,98\% pada tahap pengeringan (Gambar 1). Banyak faktor yang mempengaruhi kehilangan hasil saat panen padi. Memperhatikan fenomena 
tersebut, maka perlu dilakukan penelitian terhadap besar kehilangan hasil pada proses panen dan pascapanen padi, estimasi nilai kerugiannya, dan apa saja faktor penyebabnya. Penanganan kehilangan hasil pasca panen padi, dapat menjadi salah satu alternatif yang dapat dilakukan untuk meningkatkan persediaan beras, sehingga mengurangi impor dan pada akhirnya dapat memenuhi kebutuhan beras nasional. Ketersediaan beras yang cukup merupakan representasi dari ketahanan pangan di Indonesia.

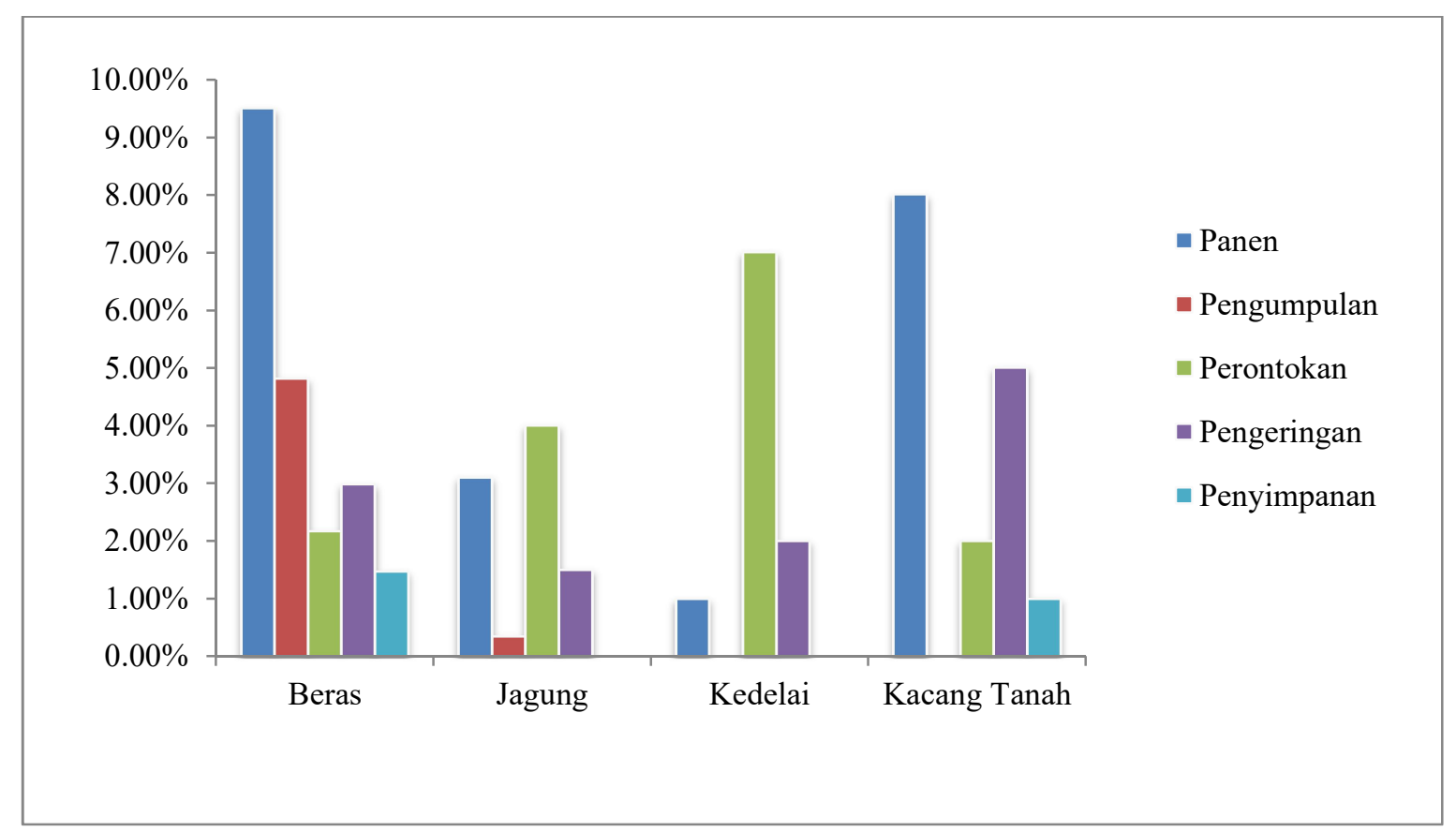

Gambar 1. Persentase Kehilangan Hasil Serelia dan Kacang-Kacangan di Indonesia (Balitbangtan, 2014)

\section{METODE PENELITIAN}

Lokasi penelitian di Kabupaten Jombang. Dari 21 kecamatan dipilih 3 kecamatan sebagai sampel dalam kegiatan ini dengan metode sengaja (purposive sampling). Kecamatan yang terpilih antara lain Kecamatan Mojowarno, Kecamatan Ngoro, dan Kecamatan Peterongan, dengan pertimbangan ketiga kecamatan tersebut penghasil padi yang potensial dengan irigasi teknis. Dari setiap kecamatan tersebut di pilih masing-masing 30 responden untuk Kecamatan Mojowarno, 28 responden untuk Kecamatan Ngoro, dan 17 responden untuk Kecamatan Peterongan. Responden dalam penelitian ini adalah pengurus dan anggota kelompok tani yang melalukan budidaya padi, sehingga jumlah responden secara 
keseluruhan sebanyak 75 orang, dengan Metode kuota. Kegiatan penelitian ini mencakup pengukuran kehilangan hasil panen dan pascapanen padi yang dilakukan mulai dari lahan sawah petani, yaitu pada tahapan pemanenan, pengumpulan, perontokan, dan pengeringan. Data yang terkumpul dari pengumpulan data, kemudian dilakukan analisis perhitungan estimasi kehilangan hasil, pada masing-masing tingkatan proses kegiatan sebagai berikut:

1. Tahapan Pemanenan

Perkiraan kehilangan Gabah Kering Panen (GKP) pada saat pemanenan dapat dihitung menggunakan formula menurut Riska (2016). Kemudian dikalikan dengan faktor konversi sebesar 83.17/100 (faktor konversi GKP menjadi GKG) dan dikalikan $64.10 \%$ yang merupakan faktor konversi GKG ke Beras (BPS, 2018), sehingga didapatkan estimasi kehilangan beras pada saat pemanenan.

$L P=\operatorname{Prod} \times F p \times F_{V_{P G}} X F_{v_{G B}}$

Keterangan:

LP (Loss Pemanenan): Kehilangan padi pada saat pemanenan (kg GKP)

Prod : Produksi GKP (kg)

Fp : Faktor koreksi kehilangan pada saat pemanenan $(\%)$

FVPG $_{\text {P }}$ Faktor konversi GKP ke GKG

$\mathrm{Fv}_{\mathrm{GB}}$ : Faktor konversi GKG ke Beras
2. Tahapan Pengumpulan

Perkiraan kehilangan Gabah Kering Panen (GKP) pada saat perontokan dapat dihitung menggunakan formula menurut Riska (2016). Kemudian akan dikalikan dengan faktor konversi sebesar 83.17/100 (faktor konversi GKP menjadi GKG) dan dikalikan $64.10 \%$ yang merupakan faktor konversi GKG ke Beras (BPS, 2018), sehingga didapatkan perkiraan kehilangan beras pada saat pengumpulan. $\mathrm{LN}=\operatorname{Prod} \mathrm{x} F \mathrm{x} \times \mathrm{Fv}_{\mathrm{PG}} \mathrm{X} \mathrm{Fv}_{\mathrm{GB}}$

Keterangan:

LN (Loss Pengumpulan): Kehilangan padi pada saat penumpukan (kg GKP)

Prod : Produksi GKP (kg)

Fn : Faktor koreksi kehilangan pada saat penumpukan $(\%)$

$F_{V_{P G}}$ : Faktor konversi GKP ke GKG

$\mathrm{Fv}_{\mathrm{GB}}$ : Faktor konversi GKG ke Beras

3. Tahapan Perontokan

Perkiraan kehilangan Gabah Kering Panen (GKP) pada saat perontokan dapat dihitung menggunakan formula berikut menurut Riska (2016). Kemudian akan dikalikan dengan faktor konversi sebesar 83.17/100 (faktor konversi GKP menjadi GKG) dan dikalikan $64.10 \%$ yang merupakan faktor konversi GKG ke Beras (BPS, 2018), sehingga didapatkan perkiraan kehilangan beras pada saat perontokan. 
$\mathrm{LR}=\operatorname{Prod} \mathrm{x}$ Fr $\mathrm{x} \mathrm{Fv}_{\mathrm{PG}} \mathrm{X} \mathrm{Fv}_{\mathrm{GB}}$

Keterangan:

KR (Loss Perontokan): Kehilangan padi pada saat perontokan (kg GKP)

Prodx : Produksi GKG tahun-x (kg)

Fr : Faktor koreksi kehilangan pada saat perontokan (\%)

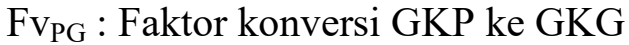

$\mathrm{Fv}_{\mathrm{GB}}$ : Faktor konversi GKG ke Beras

4. Tahapan Pengeringan

Perkiraan kehilangan Gabah Kering Panen (GKP) pada saat pengeringan dapat dihitung menggunakan formula berikut menurut Riska (2016). Kemudian akan dikalikan dengan faktor konversi sebesar 83.17/100 (faktor konversi GKP menjadi GKG) dan dikalikan 64.10\% yang merupakan faktor konversi GKG ke Beras (BPS, 2018), sehingga didapatkan estimasi kehilangan beras pada saat pengeringan.

$\mathrm{LK}=\operatorname{Prod} \times \mathrm{Fk} \times \mathrm{FV}_{\mathrm{PG}} \mathrm{X} \mathrm{Fv}_{\mathrm{GB}}$

Keterangan:

LK (Loss Pengeringan): Kehilangan padi pada saat pengeringan ( $\mathrm{kg} \mathrm{GKP}$ )

Prodx : Produksi GKG tahun-x (kg)

Fk : Faktor koreksi kehilangan pada saat pengeringan $(\%)$

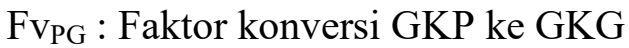

$\mathrm{Fv}_{\mathrm{GB}}$ : Faktor konversi GKG ke Beras

Faktor yang mempengaruhi kehilangan hasil diperoleh dengan melakukan uji asumsi klasik dan analisis regresi linier berganda dengan model regresi sebagai berikut:

$\mathrm{Y}=\mathrm{bo}+\mathrm{b} 1 \mathrm{X}+\mathrm{b} 2 \mathrm{D} 1+\mathrm{b} 3 \mathrm{D} 2+\mathrm{b} 4 \mathrm{D} 3+$ b5D4 + b6D5 + b7D6 + $\mu$

Keterangan:

$\mathrm{Y}=$ Kehilangan Hasil Panen Komoditas Padi (kg)

bo $=$ intersep

$\mathrm{b} 1-\mathrm{b} 7=$ koefisien regresi

$\mathrm{X}=$ Luas Lahan

$\mathrm{D} 1=$ Umur panen $(\mathrm{D}=1$ Apabila panen $>100$ hari, $\mathrm{D}=0$ Apabila panen $<100$ hari)

D2 = Perilaku Petani $(\mathrm{D}=1$ Apabila petani mengabaikan kehilangan hasil panen, $\mathrm{D}=0$ Apabila petani tidak mengabaikan kehilangan hasil panen)

D3 = Varietas $[\mathrm{D}=1$ Apabila dengan Varietas mudah rontok (Logawa dan Inpari 20), $\mathrm{D}=0$ Apabila dengan Varietas yang tahan rontok (Varietas padi Inpari, Ciherang, dan Way Apo Buru)] D4 = Alat dan Cara Panen $(\mathrm{D}=0$ Apabila dengan alat dan cara tradisional, $\mathrm{D}=1$ Apabila dengan alat dan cara modern)

$\mathrm{D} 5=$ Alat Perontok $(\mathrm{D}=0$ Apabila dengan alat perontok Power Thresser, D $=1$ Apabila dengan alat perontok Combine Harvester) 
D6 $=$ Musim $(\mathrm{D}=1$ Apabila musim kemarau, $\mathrm{D}=0$ Apabila musim hujan) $\mu=$ error

Upaya yang dapat dilakukan petani dan Pemerintah dapat diketahui dengan analisis deskriptif dari hasil temuan studi dan respon dari beberapa aktor.

\section{HASIL DAN PEMBAHASAN}

\section{Jumlah Kehilangan Hasil Panen Padi}

\section{dan Estimasi Nilai Kerugiannya}

Kegiatan pascapanen meliputi kegiatan pemanenan, penumpukan, perontokan, dan pengeringan. Berdasarkan hasil perhitungan yang dilakukan pada petani responden diperoleh angka besar kehilangan hasil pasca panen yakni $12,7 \%$. Titik kritis kehilangan hasil terjadi pada tahapan pemanenan $(7,2 \%)$ dan pengeringan $(2,48 \%)$. Hal ini membuktikan bahwa kehilangan hasil panen dalam 1 hektar adalah $794,3 \mathrm{~kg}$ beras dan nilai kerugian Rp. 5.403.889,4,- per hektar. Temuan ini manakala dianalisis lebih jauh, maka sesungguhnya kehilangan hasil panen pada petani responden sebesar 22894,39 $\mathrm{kg}$ beras. Jumlah tersebut dapat memenuhi kebutuhan beras penduduk sebesar 76.315 jiwa. Berdasarkan data bahwa seseorang membutuhkan beras 300 grm/hari sesuai anjuran Pola Pangan Harapan (PPH) di Kabupaten Jombang. Sehingga kehilangan pada saat panen di tingkat petani dapat digunakan untuk memenuhi sekitar $6.06 \%$ dari total jumlah penduduk Kabupaten Jombang yang pada Tahun 2019 berjumlah 1.258.618 jiwa. Total kehilangan hasil panen tiap petani dengan rata-rat luas lahan 0.375 ha terlihat pada Tabel 1 .

Tabel 1. Total Kehilangan Hasil Panen Padi Petani Responden di Kabupaten Jombang

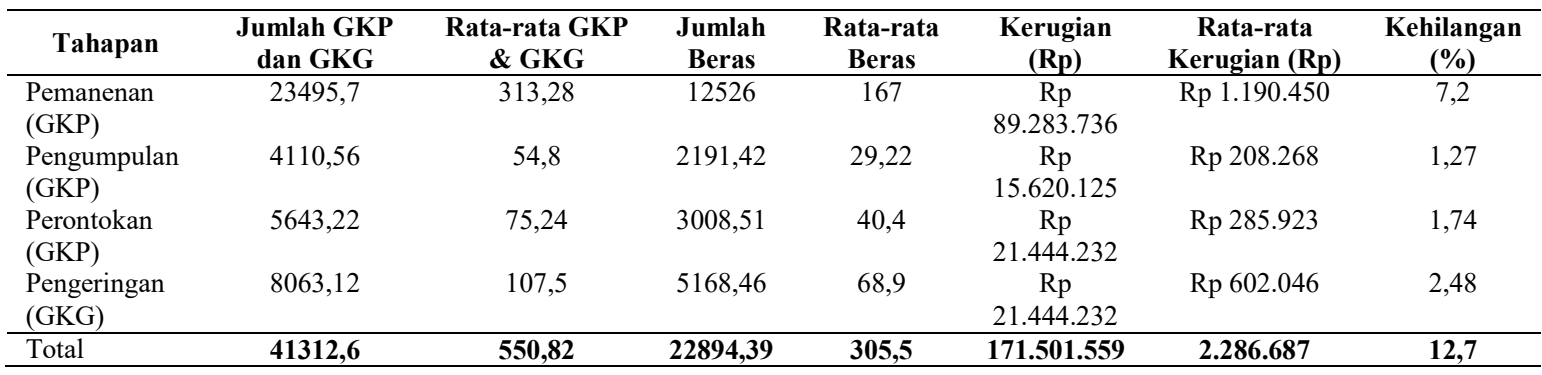

Sumber: Data Primer Diolah, 2020

Kehilangan hasil panen komoditas padi di Kabupaten Jombang pada petani responden jauh lebih tinggi yakni 12.7\% dibandingkan dengan dengan kehilangan hasil panen Kabupaten Jombang pada tahun 2019 yakni 11.46\%. Hal ini disebabkan pada tahapan pemanenan terjadi kehilangan hasil sebesar 7.2\% dan 
jauh lebih tinggi dibandingkan dengan kehilangan hasil panen pada tahapan pemanenan di Kabupaten Jombang tahun 2019 yang hanya 3.2\%. Hal ini terjadi karena pada musim panen petani responden lebih banyak yang masih menggunakan alat dan cara panen tradisional dibanding alat dan cara panen modern. Banyaknya tanaman padi yang rebah menjadi salah satu alasan petani memilih panen dengan sabit atau cara tradisional. Menurut Iswari (2012), alat panen sabit tradisional dapat mengakibatkan kehilangan hasil panen yang cukup tinggi yakni sebesar 9,52\% sementara apabila petani menggunakan alat panen sabit bergerigi, kehilangan hasil yang ditimbulkan berkurang menjadi 7,80\%. Apabila dibandingkan dengan hasil penelitian Balitbangtan (2014), maka jumlah kehilangan hasil panen pada tahapan pemanenan petani responden jauh lebih rendah dibandingkan dengan data kehilangan hasil pada tahapan pemanenan dari Balitbangtan (2014), yakni sebesar 9.49\% dari total produksi beras di Indonesia. Pada tahapan pengumpulan dan perontokan, kehilangan hasil petani responden lebih kecil dibandingkan dengan kehilangan hasil panen di Kabupaten Jombang pada tahun 2014, hal ini disebabkan bahwa sebanyak 21 responden menggunakan alat panen dan perontokan combine harvester sehingga petani tidak melewati tahapan pengumpulan saat panen dan kehilangan panen tahapan pengumpulan untuk petani yang menggunkan alat panen dan perontokan combine harvester sebanyak $0 \%$.

Faktor Yang Memepengaruhi Kehilangan Hasil Panen Komoditas Padi

Analisis regresi berganda digunakan untuk menentukan besarnya pengaruh variabel umur panen, luas lahan, perilaku petani, varietas, alat dan cara panen, alat perontok dan musim terhadap kehilangan hasil panen komoditas padi di kabupaten jombang. Dari hasil output SPSS diperoleh persamaan regresi sebagai berikut:

$$
\begin{aligned}
\mathrm{Y}= & 3,079-+22.577 \mathrm{X}-0.738 \mathrm{D} 1+ \\
& \text { 1,941D2 + 2,151D3 - 3,545D4 - } \\
& \text { 3,593D5 - 0,361D6 }
\end{aligned}
$$

Dari persamaan regresi tersebut dapat diinterpresasikan sebagai berikut:

a. Nilai konstanta regresi sebesar 3,079, menunjukkan bahwa pada luas lahan,umur panen, perilaku petani, cara panen, alat perontok serta musim dengan kondisi konstan atau $\mathrm{X}=0$, 
maka kehilangan hasil panen komoditas padi di Kabupaten Jombang sebesar 3,079.

b. X (Luas Lahan) koefisien regresinya sebesar 22.577, mempunyai pengaruh yang positif terhadap Y (Kehilangan Hasil Panen Komoditas Padi). Artinya apabila luas lahan semakin tinggi atau bertambah 1 satuan dengan asumsi variabel lain konstan, maka hal tersebut dapat meningkatkan kehilangan hasil panen komoditas Padi di Kabupaten Jombang sebesar 22.577 .

c. D1 (Umur Panen) koefisien regresinya sebesar $\quad-\quad 0.738$. mempunyai perbedaan yang negative terhadap Y (Kehilangan Hasil Panen Komoditas Padi), artinya terdapat perbedaan kehilangan hasil panen antara umur panen $>100$ hari dan umur panen $<100$ hari. Secara matematis, jika umur panen berubah dari umur panen $<100$ hari menjadi $>100$ hari (dari 0 ke 1), maka nilai kehilangan hasil panen akan turun sebesar 0.738 poin. Namun perbedaan kehilangan hasil panen antara umur panen $<100$ hari dengan umur panen $>100$ hari tidak signifikan.

d. D2 (Perilaku Petani) koefisien regresinya sebesar 1,941 , mempunyai perbedaan yang positif terhadap $\mathrm{Y}$ (Kehilangan Hasil Panen Komoditas Padi). Artinya terdapat perbedaan kehilangan hasil panen antara perilaku petani yang mengabaikan kehilangan hasil panen dengan perilaku petani yang memperhatikan kehilangan hasil panen. Secara matematis, jika perilaku petani berubah dari memperhatikan kehilangan panen menjadi mengabaikan kehilangan hasil panen (dari 0 ke 1), maka nilai kehilangan hasil panen akan bertambah sebesar 1,941 poin.

e. D3 (Varietas) koefisien regresinya sebesar 2,151, mempunyai perbedaan yang positif terhadap Y (Kehilangan Hasil Panen Komoditas Padi). Artinya terdapat perbedaan kehilangan hasil panen antara varietas mudah rontok dengan varietas tahan rontok. Secara matematis, jika varietas berubah dari varietas tahan rontok menjadi varietas mudah rontok (dari 0 ke 1), maka nilai kehilangan hasil panen akan bertambah sebesar 2,151 poin.

f. D4 (Alat dan Cara Panen) koefisien regresinya sebesar - 3,545, mempunyai perbedaan yang negatif terhadap Y (Kehilangan Hasil Panen Komoditas Padi). Artinya terdapat perbedaan kehilangan hasil panen 
antara alat dan cara panen tradisional dengan alat dan cara panen modern. Secara matematis, jika alat dan cara panen berubah dari alat dan cara panen tradisional menjadi alat dan cara panen modern (dari 0 ke 1), maka nilai kehilangan hasil panen akan berkurang sebesar 3,545 poin.

g. D5 (Alat Perontok) koefisien regresinya sebesar $-3,593$, mempunyai perbedaan yang negatif terhadap Y (Kehilangan Hasil Panen Komoditas Padi). Artinya terdapat perbedaan kehilangan hasil panen alat perontok power thresher dengan alat perontok combine harvester. Secara matematis, jika alat perontok berubah dari power threser menjadi combine harvester (dari 0 ke 1), maka nilai kehilangan hasil panen akan berkurang sebesar 3,593 poin.

D6 (Musim) koefisien regresinya sebesar - 0,361, mempunyai pengaruh yang negatif terhadap Y (Kehilangan Hasil Panen Komoditas Padi). Artinya terdapat perbedaan kehilangan hasil panen antara musim kemarau dengan musim hujan. Secara matematis, jika musim berubah dari musim hujan menjadi musim kemarau (dari 0 ke 1), maka nilai kehilangan hasil panen akan turun sebesar 0.361 poin. Namun perbedaan kehilangan hasil panen antara musim kemarau dengan musim hujan tidak signifikan.

Berikut adalah hasil estimasi faktor-faktor yang menjadi pengaruh terhadap kehilangan hasil panen komoditas padi setelah memenuhi asumsi-asumsi klasik. Dari hasil analisis akhir didapatkan 5 faktor yang mempengaruhi kehilangan hasil panen (Y) secara nyata yaitu Luas Lahan (X), Perilaku Petani (D2), Varietas (D3), Alat dan Cara Panen(D4), serta Alat Perontok (D5).

Tabel 2 Hasil Uji Parsial

\begin{tabular}{|c|c|c|c|c|c|}
\hline Variabel & $\mathbf{t}_{\text {hitung }}$ & $\mathbf{t}_{\text {tabel }}$ & \multicolumn{2}{|c|}{ Prob. Sig } & Keterangan \\
\hline Luas Lahan (X) & 11,442 & 1,998 & 0,000 & 0,05 & Berpengaruh Signifikan \\
\hline Umur Panen (D1) & 0.803 & 1,998 & 0,425 & 0,05 & Tidak Berbeda Signifikan \\
\hline Perilaku Petani (D2) & 2,405 & 1,998 & 0,019 & 0,05 & Berbeda Signifikan \\
\hline Varietas (D3) & 2,321 & 1,998 & 0,023 & 0,05 & Berbeda Signifikan \\
\hline Alat dan Cara Panen (D4) & 2,905 & 1,998 & 0,005 & 0,05 & Berbeda Signifikan \\
\hline Alat Perontok (D5) & 3,320 & 1,998 & 0,001 & 0,05 & Berbeda Signifikan \\
\hline Musim (D6) & 0.416 & 1,998 & 0,679 & 0,05 & Tidak Berbeda Signifikan \\
\hline
\end{tabular}




\section{Pengaruh Variabel Luas Lahan terhadap Kehilangan Hasil Panen Komoditas Padi}

Hasil perhitungan membuktikan bahwa variabel luas lahan berpengaruh signifikan terhadap kehilangan hasil panen beras. Hal ini disebabkan karena petani responden yang memiliki lahan lebih luas cenderung menggunakan alat dan cara panen modern serta alat perontok modern sehingga kehilangan hasil panen lebih kecil dibandingkan petani memiliki luas lahan sempit yang pada realitasnya masih menggunakan alat tradisional. Tentu saja secara rasionalitas karena faktor besarnya biaya yang harus dikeluarkan. Persentase kehilangan hasil panen petani responden pada tahapan pengumpulan juga cenderung lebih rendah dibandingkan dengan data dari Dinas Pertanian Kabupaten Jombang Tahun 2019, hal ini dikarenakan sebanyak 21 petani responden menggunakan alat dan cara panen modern memiliki luas lahan yang cukup luas sehingga tidak terjadi tahap pengumpulan atau dapat dikatakan kehilangan hasil sebesar $0 \%$ dan menurunkan persentase total kehilangan hasil panen responden petani pada tahapan pengumpulan.

\section{Pengaruh Variabel Umur Panen terhadap Kehilangan Hasil Panen Komoditas Padi}

Berdasarkan hasil analisis, variabel umur panen padi tidak berpengaruh signifikan terhadap kehilangan hasil panen padi. Secara parsial tidak ada perbedaan kehilangan hasil panen komoditas padi yang ditanggung petani antara umur panen $<100$ hari dengan umur panen $<100$ hari. Hal ini disebabkan karena selisih umur panen yang diterapkan oleh petani tidak terlalu jauh sehingga tidak ada perbedaan yang signifikan.

\section{Pengaruh Variabel Perilaku Petani terhadap Kehilangan Hasil Panen Komoditas Padi}

Bahwa variabel perilaku petani berpengaruh signifikan terhadap kehilangan hasil panen padi. Perilaku petani dipengaruhi oleh budaya dan tradisi yang ada pada daerah tersebut, kurang memperhatikan dan kurang menyadari bahwa sebenarnya apa yang dilakukan sudah memenuhi kriteria kehilangan hasil. Sebagai contoh perilaku petani yang tidak menegur pemanen apabila pemanen tidak berhati-hati saat melakukan pemanenan sehingga banyak gabah tercecer dilahan, hal ini dapat dilihat pada saat lahan diolah dan akan 
ditanami kembali. Tampak pada lahan sudah tumbuh tanaman padi kecil akibat dari gabah yang tercecer di lahan. Selain itu perilaku petani yang tidak menggunakan alas pada saat mengumpulkan padi sebelum dirontokkan membuat kehilangan hasil pada tahap pengumpulan semakin tinggi.

\section{Pengaruh Variabel Varietas terhadap Kehilangan Hasil Panen Padi}

Variabel varietas berpengaruh signifikan terhadap kehilangan hasil panen padi. Rata-rata kehilangan hasil panen petani yang menggunakan varietas mudah rontok (Logawa) sebesar 316,47 $\mathrm{kg}$ gabah dengan rata-rata kerugian yang ditanggung petani sebesar Rp. $2.370 .832,-$. Sedangkan untuk petani yang menggunakan varietas padi tahan rontok (varietas Inpari 32, Ciherang, dan Way Apu Buru) sebesar 269,8 kg gabah dengan nilai kerugian Rp. 2.020.229,-. Petani responden yang menggunakan varietas tahan rontok yakni sebanyak 18 petani dari total responden. Sedangkan sisanya menggunakan varietas yang mudah rontok sebanyak 57 petani responden. Perbedaan kehilangan hasil panen padi yang dialami oleh petani antara varietas yang mudah rontok dan varietas tahan rontok sesuai dengan penelitian yang dilakukan oleh Nugraha, Thahir dan Sudaryono (2007).

\section{Pengaruh Variabel Alat dan Cara Panen terhadap Kehilangan Hasil Panen Padi \\ Terdapat perbedaan pengaruh} signifikan terhadap kehilangan hasil panen padi penggunaan alat dan cara panen padi. Hal ini yang membuktikan fenomena tersebut di lokasi penelitian, sebagaimana dilakukan oleh petani responden. Hasil dan temuan di lapangan sejalan dengan beberapa penelitian panen dengan sabit tradisional memiliki tingkat kehilangan $9,52 \%$ sedangkan panen dengan sabit bergerigi memiliki tingkat kehilangan 7,80\% sehingga lebih rendah $1,72 \%$ dari pada dengan sabit tradisional. Begitupula dengan alat panen modern seperti panen dengan reaper memiliki tingkat kehilangan hasil $6 \%$, alat paddy mover memiliki tingkat kehilangan hasil $2 \%$ serta alat combine harvester yang memiliki tingkat kehilangan sebesar 2,55\% (Iswari, 2012). Dengan demikian semakin modern alat yang digunakan oleh petani pada suatu daerah maka kehilangan hasil panen akan semakin kecil. 


\section{Pengaruh Variabel Alat Perontok terhadap Kehilangan Hasil Panen Padi}

Hasil analisis menunjukkan bahwa variabel alat perontok berpengaruh signifikan terhadap kehilangan hasil panen padi. Hal ini dibuktikan dengan perhitungan besar kehilangan hasil panen petani responden pada tahapan perontokan sebesar $1,74 \%$; dan nilai ini lebih rendah dibandingkan dengan data dari Dinas Pertanian Kabupaten Jombang Tahun 2019 yakni sebesar 3,06\%. Rendahnya kehilangan hasil panen pada perontokan ini disebabkan karena petani responden tidak ada yang menggunakan alat perontok tradisional yakni dengan cara dibanting (gebot) yang memiliki tingkat kehilangan sebesar 4,79\% (Iswari, 2012).

\section{Pengaruh Variabel Musim terhadap Kehilangan Hasil Panen Padi}

Bahwa variabel musim tidak berpengaruh signifikan terhadap kehilangan hasil panen padi. Salah satu alasan yang dapat dikemukakan adalah adanya realitas pergeseran periode masa tanam dan masa panen yang saat ini sulit diprediksi akibat adanya perubahan iklim (climate change). Hal ini sejalan dengan data dari BPS (2020), bahwa curah hujan di Kkabupaten Jombang pada bulan April 2020 rata-rata berkisar antara $151-200$ mm yang termasuk dalam kriteria curah hujan menengah dimana pada bulan April 2020 seharusnya merupakan puncak masa panen padi di Kabupaten Jombang untuk periode masa tanam tersebut.

Nilai korelasi atau (R) mengartikan seberapa erat atau kuat hubungan antara umur panen, luas lahan, perilaku petani, varietas, alat dan cara panen, alat perontok dan musim adalah sangat kuat dimana nilai $\mathrm{R}=0.842>0.5$ sedangkan nilai koefisien determinasi atau (R2) pada sebesar $70.9 \%$.yang mengartikan bahwa variabel kehilangan hasil panen dapat dijelaskan oleh variabel independen (bebas) sebesar 70.9\% dan sisanya sebesar $29.1 \%$ yang dijelaskan oleh faktor lainnya yang tidak termasuk ke dalam model.

\section{Upaya dan Tidndakan Starategis} Petani dan Pemerintah dalam mengurangi Kehilangan Hasil Panen

\section{Komoditas Padi di Kabupaten Jombang}

Merujuk pada temuan di lapangan dan hasil kajian analisis penelitian, maka Berikut disajikan beberapa upaya dan tindakan strategis yang seharusnya dilakukan petani dan pemerintah untuk 
mengurangi kehilangan hasil panen padi guna mendukung ketahanan pangan

1. Petani mengoptimalkan tenaga kerja dari dalam keluarganya untuk mengurangi penggunaan tenaga pemanen dengan cara borongan

Untuk menghemat waktu dan tenaga petani biasanya melakukan panen dengan cara mempekerjakan tenaga borongan, bahkan jika gabah di beli di lahan, tengkulak akan melakukan pemanenan dengan rombongan tenaga kerjanya yang jumlahnya sangat banyak. Salah satu pertimbangannya adalah masalah kecepatan waktu agar segera dapat memetik hasil tanpa memperhitungkan masalah seberapa besar kehilangan hasil panen yang diakibatkan dengan cara perlakuan demikian. Padahal cara-cara demikian terbukti banyak hasil panen yang hilang (food loss). Di sisi tenaga borongan akan menguntungkan dirinya, karena semakin cepat selesai, maka ia akan segera beranjak ke tempat lain untuk melakukan pekerjaan sejenis dengan cara borongan tersebut, sehingga dapat memperoleh keuntungan yang lebih bagi yang bersangkutan. Hal ini dapat dikerjakan, mengingat saat panen diperkirakan waktu panennya bisa bersamaan.

\section{Petani melakukan Panen Tepat Waktu}

Pemanenan dilakukan setelah sebagian besar (90-95\%) gabah telah bernas dan menguning. Panen tepat pada waktunya sangat penting, terlalu awal akan banyak gabah hampa sedang jika panen terlambat mak akan banyak gabah yang rontok dan gabah patah waktu digiling. Panen yang tidak tepat waktu dapat meningkatkan kehilangan hasil panen.

\section{Petani mengurangi perontokan gabah di rumah}

Perontokan gabah di rumah dengan cara membawa padi sedikit demi sedikit ke rumah kemudian di rontokkan di rumah. Cara ini biasa dilakukan karena kebutuhan pakan untuk ternak, jika melakukan perontokan di lahan atau panen langsung di lahan maka tidak akan ada jerami padi yang tersisa karena diminta oleh petani atau peternak lain.

Kebiasaan petani tersebut dapat memperbesar kehilangan hasil yang ditanggung oleh petani. Hal ini disebabkan saat petani melakukan pengangkutan malai padi ke rumah maka akan banyak butir padi yang rontok selama perjalanan selain itu akan banyak padi yang tercecer disaat pengumpulan di rumah. Akan lebih efektif jika melakukan 
perontokan di lahan dan apabila membutuhkan jerami untuk pakan ternak maka petani dapat membawa jerami setelah perontokan ke rumah sehingga kehilangan hasil panen yang yang tercecer di jalan saat proses pengangkutan ke rumah petani dapat dihindari dan kerugian kehilangan hasil panen yang ditanggung petani dapat berkurang.

\section{Petani mengurangi penggunaan}

\section{Varietas padi mudah rontok}

Ada beberapa varietas padi yang mudah rontok, seperti varietas Logawa yang masih banyak digunakan oleh petani di Kabupaten Jombang. Tingkat kerontokan yang tinggi bisa berkaibat mudah jatuhnya bulir gabah terutama karena adanya sentuhan, baik itu karena di tumpuk dulu di pematang atau karena bersentuhan engan tubuh petani dan alat pemotong padi. Varietas padi yang mudah rontok perlu mendapat perhatian khusus terutama saat pengangkutan ke lokasi perontokan harus di berikan alas dengan karung ataupun terpal sehingga jika gabah jatuh akan tertampung di alas tersebut.

\section{Petani mengurangi pengumpulan sebelum perontokan}

Pengumpulan yang terlalu lama membuat gabah lepas dengan sendirinya

sehingga jika tidak segera di erek atau dirontokkan dengan alat perontok padi maka banyak bulir gabah yang jatuh. Untuk itu pengumpulan padi harus dilakukan setelah di potong dan diberikan alas dibawahnya dengan luasan yang cukup. Perontokan dilakukan sebaiknya maksimal 1-2 hari setelah panen, dan gabah dari hasil perontokan harus segera dibersihkan dan dijemur.

Berikut adalah beberapa tindakan strategis yang dapat dilakukan oleh Pemerintah dalam menyikapi kehilangan hasil komoditas padi diantaranya:

1. Pemerintah

kemampuan dan keterampilan petani

Pelatihan dan pembinaan petani untuk menunjang keberhasilan dalam penerapan teknologi penanganan kehilangan hasil, sebaiknya disiapkan terlebih dahulu dengan upaya perbaikan penanganan pascapanen sebaiknya dimulai dengan peningkatan kemampuan dan ketrampilan petani dalam hal pascapanen padi, yang dimulai dengan pengenalan tahapan pascapanen, titik kritis tahapan pascapanen yang dapat menimbulkan potensi kehilangan serta cara mengatasi atau menekan kehilangan tersebut. 


\section{Pemerintah}

Memanfaatkan teknologi tepat guna sesuai lokasi

Teknologi penanganan kehilangan hasil yang dipilih untuk diterapkan harus teknologi yang sesuai dengan spesifik lokasi. Teknologi tersebut tidak bertentangan dengan masyarakat pengguna, baik secara teknis, ekonomis maupun sosial budaya masyarakat setempat. Sebagai contoh, dalam pembentukan sistem panen beregu terdapat perbedaan pada masing-masing lokasi atau daerah. Pada daerah dengan pemilikan lahan sempit, penerapan teknologi yang dapat dilakukan yaitu dengan cara pengembangan sistem panen beregu dengan anggota 5 - 7 orang yang dilengkapi dengan 1 unit pedal thresher. Sedangkan ditempat lain dapat dikembangkan sistem panen beregu dengan anggota 15 - 20 orang yang dilengkapi 1 unit power thresher.

\section{Pemerintah membentuk dan}

\section{memberdayakan kelompok Tani}

Upaya perbaikan penanganan dan penanganan kehilangan hasil panen dengan penerapan teknologi panen yang baru, sebaiknya dilakukan secara berkelompok yang bersifat komersial dan mandiri, baik oleh kelompok tani, regu panen, dan pengusaha jasa alsintan dengan cara membentuk kelembagaan jasa pemanen, jasa perontok, jasa penjemuran, dan jasa penggilingan, sehingga nilai tambah yang diperoleh dapat dirasakan oleh seluruh anggota kelompok

\section{KESIMPULAN DAN SARAN}

\section{Kesimpulan}

1. Total kehilangan hasil panen komoditas padi di Kabupaten Jombang $12,7 \%$ yakni $794,35 \mathrm{~kg}$ beras dan nilai kerugian Rp.5.945.386,2,- per hektar.

2. Variabel luas lahan, perilaku petani, varietas, alat dan cara panen, dan alat perontok berpengaruh terhadap kehilangan hasil panen komoditas padi

3. Upaya dan tindakan strategis yang dapat dilakukan petani untuk mengurangi kehilangan hasil penen komoditas padi yakni mengurangi penggunaan tenaga pemanen dengan cara borongan, panen tepat waktu, mengurangi perontokan gabah di rumah, mengurangi penggunaan Varietas padi mudah rontok dan mengurangi pengumpulan sebelum perontokan. Sedangkan upaya dan tindakan strategis pemerintah untuk mengurangi kehilangan hasil ialah melakukan penguatan kapasitas dan 
keterampilan petani (capacity building), memanfaatkan teknologi tepat guna sesuai lokasi, membentuk dan memberdayakan Kelompok Tani.

\section{Saran}

1. Petani dapat mengurangi kehilangan hasil panen dengan menggunakan pemotong padi sabit bergerigi untuk cara panen tradisional dan combine harvester.Pada tahapan penumpukan padi dan pengangangkutan menggunakan alas plastik.

2. Bagi peneliti selanjutnya, agar dapat melakukan penelitian kehilangan hasil yang dihasilkan tahapan lainnya seperti tahapan penyimpanan, tahapan pengangkutan, tahapan penggilingan dan tahapan distribusi serta menambah jumlah sampel yang akan di teliti sehingga dapat diketahui sumber-sumber kehilangan hasil yang seharusnya masih dapat dikendalikan.

3. Bagi peneliti selanjutnya juga dapat melakukan dengan menambah variabel lain yang menjadi faktor kehilangan hasil yang belum diteliti.

\section{DAFTAR PUSTAKA}

Badan Pusat Statistik Indonesia. 2018. Survei Konversi Gabah ke Beras 2018. Jakarta Pusat: Badan Pusat Statistik

Dinas Pertanian Kabupaten Jombang.
2019. Data Kehilangan Hasil Panen Padi.

Food and Agriculture Organization of the United Nation. 2011. Global Food Losses and Food Waste-Extent, Causes and Prevention. Roma (IT): UN FAO.

. 2013. The State of Food Insecurity in the World. Roma (IT): FAO.

. 2014. Global Initiative of Food Losses and Waste Reduction. Roma (IT): FAO.

Hasbullah, R. 2010. Gerakan Nasional Penurunan Susut Pascapanen, Suatu Upaya Menanggulangi Krisis Pangan. Institut Pertanian Bogor. . dan A.R. Dewi. 2012. Teknik Penanganan Pascapanen Padi untuk Menekan Susut dan Meningkatkan Rendeman Giling. Jurnal Pangan. Vol.21. No.1. pp 17-28

Iswari, K. (2012). Kesiapan Teknologi Panen dan Pascapanen Padi dalam Menekan Kehilangan Hasil dan Meningkatkan Mutu Beras. Jurnal Litbang Pertanian, 31(2), 58-67.

Nugraha, S., R. Thahir, dan Sudaryono. 2007. Keragaan Kehilangan Hasil Pascapanen Padi pada 3 (Tiga) Agroekosistem. Buletin Teknologi Pascapanen Pertanian. Vol.3

Riska, A. M.. 2016. Perkiraan kehilangan pangan ( food loss dan food waste) komoditas beras di indonesia. Institut Pertanian Bogor.

Setyono A, Sutrisno S, Nugraha, Jumali. 2007. Application of Group Harvesting Technique for Rice Farming Second Edition. Sukamandi(ID): Indonesian Center for Rice Research.

. A., N. Sigit, dan Sutrisno. 2009. Prinsip Penanganan Pascapanen Padi. Balai Besar Penelitian Tanaman Padi. Balai Besar Penelitian dan Pengembangan Pascapanen Pertanian. 
http://www.litbang.pertanian.go.id/ special/padi/bbpadi_2009_itkp_18.

pdf. Diakses pada $\overline{06}$ Januari 2020 